Article

\title{
A Bronze Reliquary for an Ichneumon Dedicated to the Egyptian Goddess Wadjet
}

\author{
Robert Steven Bianchi
}

The Ancient Egyptian Museum Shibuya, Tokyo 150-0041, Japan; drbobbianchi@gmail.com

\begin{abstract}
This is a short introduction to the hieroglyphic nature of ancient Egyptian material culture and its polyvalence using a bronze statuette of a lioness-headed goddess in front of an obelisk (formerly in the Omar Pasha Sultan Collection) as a case study. Because the lioness is not identified by an accompanying inscription, the essay demonstrates methods by which the identification and significance of the image can be unpacked.
\end{abstract}

Keywords: cat; heka; ichneumon; Leto; lioness; myth of the distant goddess; obelisk; Osiris; Sakhmet; sultan Omar pasha collection

check for updates

Citation: Bianchi, Robert Steven. 2022. A Bronze Reliquary for an Ichneumon Dedicated to the Egyptian Goddess Wadjet. Arts 11: 21. https://doi.org/10.3390/ arts11010021

Academic Editors: Branko F. van Oppen de Ruiter and Chiara Cavallo

Received: 10 September 2021

Accepted: 13 January 2022

Published: 20 January 2022

Publisher's Note: MDPI stays neutral with regard to jurisdictional claims in published maps and institutional affiliations.

Copyright: (c) 2022 by the author. Licensee MDPI, Basel, Switzerland. This article is an open access article distributed under the terms and conditions of the Creative Commons Attribution (CC BY) license (https:// creativecommons.org/licenses/by/ $4.0 /)$.
One begins with a discussion about the hieroglyphic nature of ancient Egyptian $\operatorname{art}^{1}$ by noting, first, that the tenets which govern the design of the hieroglyphs are precisely those which govern the design of ancient Egyptian visual representations. Sign and image are inseparable. More specifically, ancient Egyptian nouns and verbs are often suffixed by one or more signs that are not vocalized because they serve as unvoiced ideograms that determine their immediately preceding sound signs by attempting to provide a visual clue with regard to their meaning. ${ }^{2}$ Barbara Richter discusses the polyvalence inherent in i3s, bald, and Racheli Shalomi-Hen demonstrates how the verb, sr, to foresee, determined by a giraffe, can also connote the modern expression of "to chicken out." ${ }^{3}$ This polyvalence is emphasized by the fact that the noun 'w.t, small cattle, can be determined by any number of horned, African ruminants, ${ }^{4}$ a herd of which a modern commentator might never expect to associate with farm animals. To these individual examples can be added the extended discussions of Stephen Houston and Andréas Stauder, who demonstrate that such hieroglyphs possess a dense mode of visual communication that cannot be reduced to a single meaning. ${ }^{5}$ Their position is reinforced by Hany Rashwan, who argues that the ancient Egyptian system of determinatives is so unique in its extreme richness that its use generates multivalent meanings in each and every word. ${ }^{6}$

Because ancient Egyptian art is hieroglyphic, it is, likewise, characterized by polyvalence. As a result, the meaning, significance, and interpretation of any one entity - be it a hieroglyph, an object—real or created—or an architectural structure-are all ambivalent. The concept has already been described by others, including Erik Horning. ${ }^{7}$ Camilla Di Biase-Dyson explores this inherent polyvalence in her unpacking of a so-called inscribed, birthing brick in Berlin from a lexical point of view. She conclusively demonstrates that the inscriptions on this particular brick reveal that a papyrus scroll would have been used for the ritual purpose to which this brick was put and that the brick itself was a "stand-in" for the execution of that ritual purpose rather than facilitating it. ${ }^{8}$ Kathlyn M. Cooney discusses the multiplicity of meanings inherent in coffins of the Third Intermediate Period. Her study reveals that an ancient Egyptian coffin could be simultaneously regarded as "a home, a fortress, a tomb, temple, and even as a magical provisioning device for food." ${ }^{\prime 9}$ The same polyvalence is operative in the ancient Egyptian understanding of the function of the Temple of Isis at Dendera, which was anciently named, st-mshnt, the place of birth. ${ }^{10}$ That designation was often more narrowly defined by the use of numerous, other nuanced 


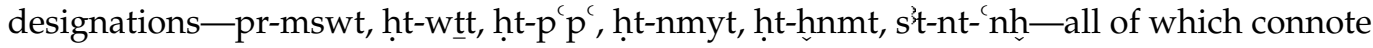
subtle differences in function, which are lost in their generic translation as a "place of birth."11 Richard Bussmann provides an informative summary of the issue of polyvalence, which he prefers to regard from a praxeological context, in which any aspect of ancient Egypt's material culture might have meant different things to different individuals. ${ }^{12}$ Accordingly, the material culture of ancient Egypt cannot be quantified by reliance upon Aristotelian categorization into which meaning, significance, and interpretation can be neatly sorted into discrete pigeon-holes. One size does not fit all (Figure 1).

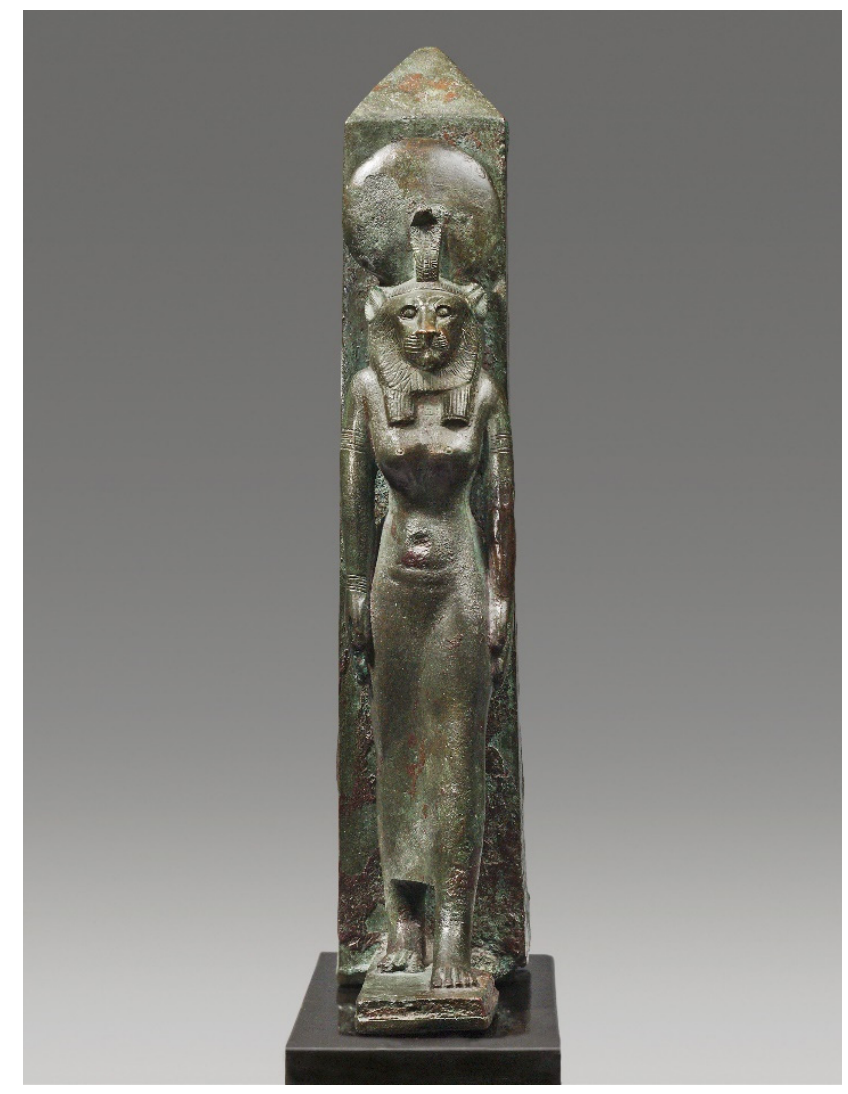

Figure 1. A bronze reliquary for an ichneumon dedicated to the Egyptian goddess Wadjet, front view. (Private collection, courtesy of the owner).

The principal figure of the group composition under discussion is a leonine-headed goddess, ${ }^{13}$ which had formerly been in the Omar Pasha Sultan collection ${ }^{14}$ She is designed striding forward on an integral plinth with her left leg advanced. Both of her arms are held parallel to the sides of her body with the palms of their hands open and pressed against her thighs. She is shown wearing a tightly-fitting sheath, the only indication of which is its hem ending just above the level of her ankles. The gossamer quality of the fine linen from which this sheath is woven reveals details of her anatomy, which includes the horizontal folds over her pubic triangle, her deeply recessed navel, and the two incised, small circles representing the nipples on her breasts. In keeping with ancient Egyptian design tenets, the fingers of her hands appear to be somewhat disproportionately long and are designed, as are the toes of her feet, without any indication of either their joints or nails. Her accessories include a pair of armlets and bracelets, designed as incised lines intended to represent an upper and lower thin, horizontal band that frames and holds into position a series of square, metope-like panels decorated with geometric designs. She wears a striated, tripartite wig, the lappets of which rest upon her upper chest. Her only attribute is a large sun disc fronted by the upright hood of a cobra, or sacred uraeus, resting upon her head (Figure 2). 


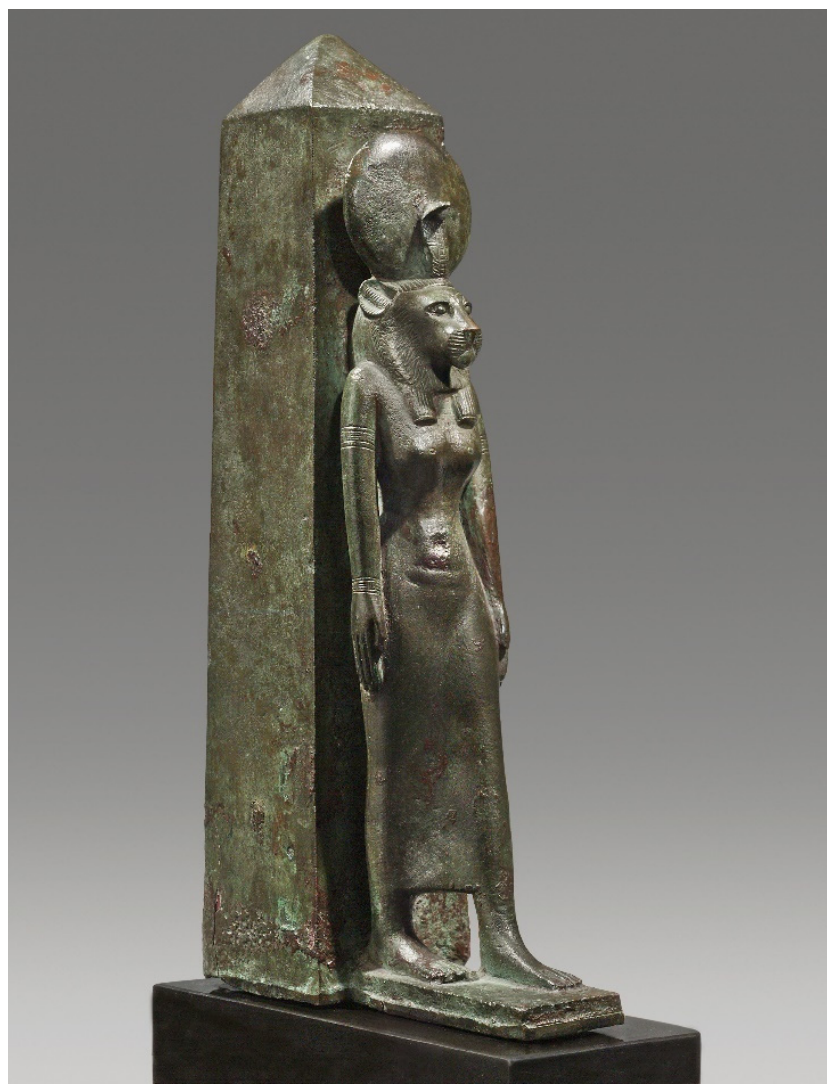

Figure 2. A bronze reliquary for an ichneumon dedicated to the Egyptian goddess Wadjet, threequarter view from the right (Private collection, courtesy of the owner).

The absence of any accompanying inscriptions initially renders the identification of this goddess moot because ancient Egyptian religious tenets mandate that one species can represent a number of different deities. ${ }^{15}$ Certain points must, therefore, be passed in review before identification can be made. Such identifications often rely upon the principle that the design of ancient Egyptian images include coded visual messages upon which an identification can be based. It is to two of these coded visual clues on this bronze group to which one now turns.

First and foremost is the observation that the breasts and articulated pubic mound clearly indicate that this leonine figure is female. Although a pharaoh is very frequently compared to a mighty lion, the overwhelming number of ancient Egyptian leonine deities are goddesses. ${ }^{16}$ And yet, contrary to popular opinion about just how naturalistic ancient Egyptian representations of animals are, a lioness in the wild does not have a mane, which is a hallmark of the male of the species. To argue that the ancient Egyptians were aware of the fact that in certain instances, a lioness may exhibit a mane ${ }^{17}$ and so replicated it in their representations is specious in the extreme because detailed studies of ancient Egyptian representations of animals have repeatedly demonstrated just how non-discriminating the ancient Egyptian were in their seemingly disregard to distinguish a jackal from a dog, ${ }^{18}$ an otter from a mongoose, ${ }^{19}$ a crocodile from a scorpion, ${ }^{20}$ and all of the horned, African ruminants from one another. ${ }^{21}$ Representations of animals served as religious and political symbols, the zoological identifications of which are often impossible to determine because there appears to have been no imperatives for the canonical representation of any given species, as the variations in the depictions of donkeys so firmly reveal. ${ }^{22}$ To insist, therefore, that the presence of a mane on a lioness is based on natural observations flies in the face of this cumulative evidence. ${ }^{23}$ 
The reason behind this apparent gender-bending conflation, the presence of a lion's mane wreathing the head of a lioness, resides in the ancient Egyptian concept of felines. The ancient Egyptian noun for lion, $p A-m A j$, and that for cat, $p A-m j w$, are virtual homonyms. ${ }^{24}$ That aural similarity is congruent with ancient Egyptian design tenets in which the visual representation of a head of a lioness is virtually indistinguishable from that of a cat. The presence of the mane on images of leonine goddesses is an intentional ancient Egyptian coded device to indicate that the goddess represented is a lioness and not a cat. ${ }^{25}$ Those aural and visual similarities are also emphasized in any number of ancient Egyptian myths in which a raging, bellicose lioness is transformed into a purring, docile pussy cat, the best example of which is found in several versions of the so-called Myth of the Distant Goddess, ${ }^{26}$ in which the sun god has misgivings about his decision to dispatch his enforcer, often a leonine goddess, to destroy humanity because of its alleged plot to revolt against him. ${ }^{27}$ A ruse ultimately restrains the rampaging leonine goddess, who is then transformed into a docile pussy cat. This pairing of seemingly opposite, antithetical concepts is a fundamental principle of ancient Egyptian religious thought processes. $^{28}$

Because the sheer number of leonine goddesses populating the ancient Egyptian pantheon is legion, identifying examples that are not accompanied by inscriptions relies upon an understanding of other coded visual messages. In this case, those coded messages are contained within this goddess's attributes. Discs fronted by the hooded heads of cobras are a common attribute of ancient Egyptian deities, both gods and goddess alike, imbuing them with solar characteristics. However, the design of this particular hooded cobra is subtly different from the expected norm because its height is disproportionately larger than expected, measuring approximately the length of a radius of the circular design of the sun disc. This iconographic, coded visual message suggests that the leonine goddess represented in this bronze object possesses a second hypostasis, or alternate form, namely, that of a cobra. This observation suggests that the goddess must be identified as Wadjet, ${ }^{29}$ the major leonine goddesses in the ancient Egyptian pantheon whose two principal hypostases are those of both a lioness and a cobra. That identification is confirmed by a number of iconographically similarly designed bronze statuettes, which are inscribed for that goddess. (Figure 3) A comparison with an example in Leiden confirms the identification because she is specifically identified by name in the hieroglyphic inscription on the base. ${ }^{30}$ The meaning of her name, $w A D j . t$, "she-of-the-papyrus," is often translated as "the green one," because of the green color of that plant. ${ }^{31}$

The cult of the ancient Egyptian goddess Wadjet can be traced back to the predynastic period of the fourth millennium $\mathrm{BCE}^{32}$ and was centered in the Delta city of Buto, ${ }^{33}$ although her temple at the site of Tebtunis in the Egyptian Faiyum was the site of ritual performances in her honor. ${ }^{34}$ She is often represented as a rearing cobra, as seen here in a vignette from the tomb of Nofertari where she is winged, attributes that allude to the function of her wings as a providing for a protective embrace as well as to their flapping in order to create the breath of life both of which are so vital for the survival of the deceased in the Hereafter. ${ }^{35}$ (Figure 4) As such, Wadjet becomes the personification of the serpentimage of kingship and appears prominently as a royal insignia of protection on the brow of pharaohs from Dynasty IV onward. (Figure 5) Wadjet is associated with Nekhbet, the vulture goddess, forming a pair named the nebty, "The-Two-Ladies," symbolizing the duality of Egypt as "The Two Lands," namely, Upper and Lower Egypt. Those symbols are often manifest in the Double Crown, the red crown of Lower Egypt represented by Wadjet, the white crown of Upper Egypt by Nekhbet. 


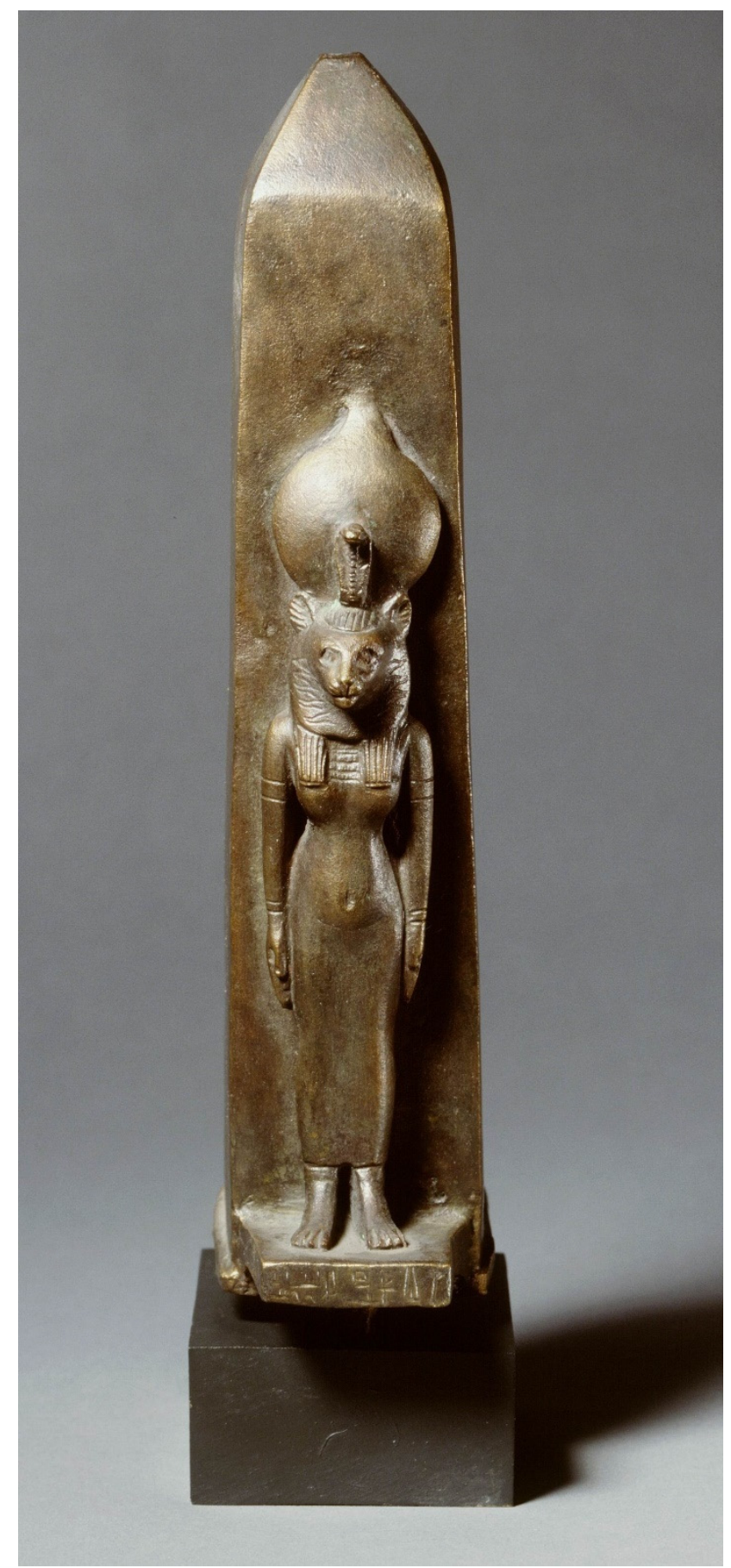

Figure 3. A bronze reliquary for an ichneumon inscribed for the Egyptian goddess Wadjet. Leiden, Rijksmuseum van Oudheden F 1953/5.2. (https://www.rmo.nl/collectie/collectiezoeker/ collectiestuk/ ?object=13099, accessed on 24 September 2021) Images from the National Museum of Antiquities are freely available for re-use by developers under a Creative Commons license. 


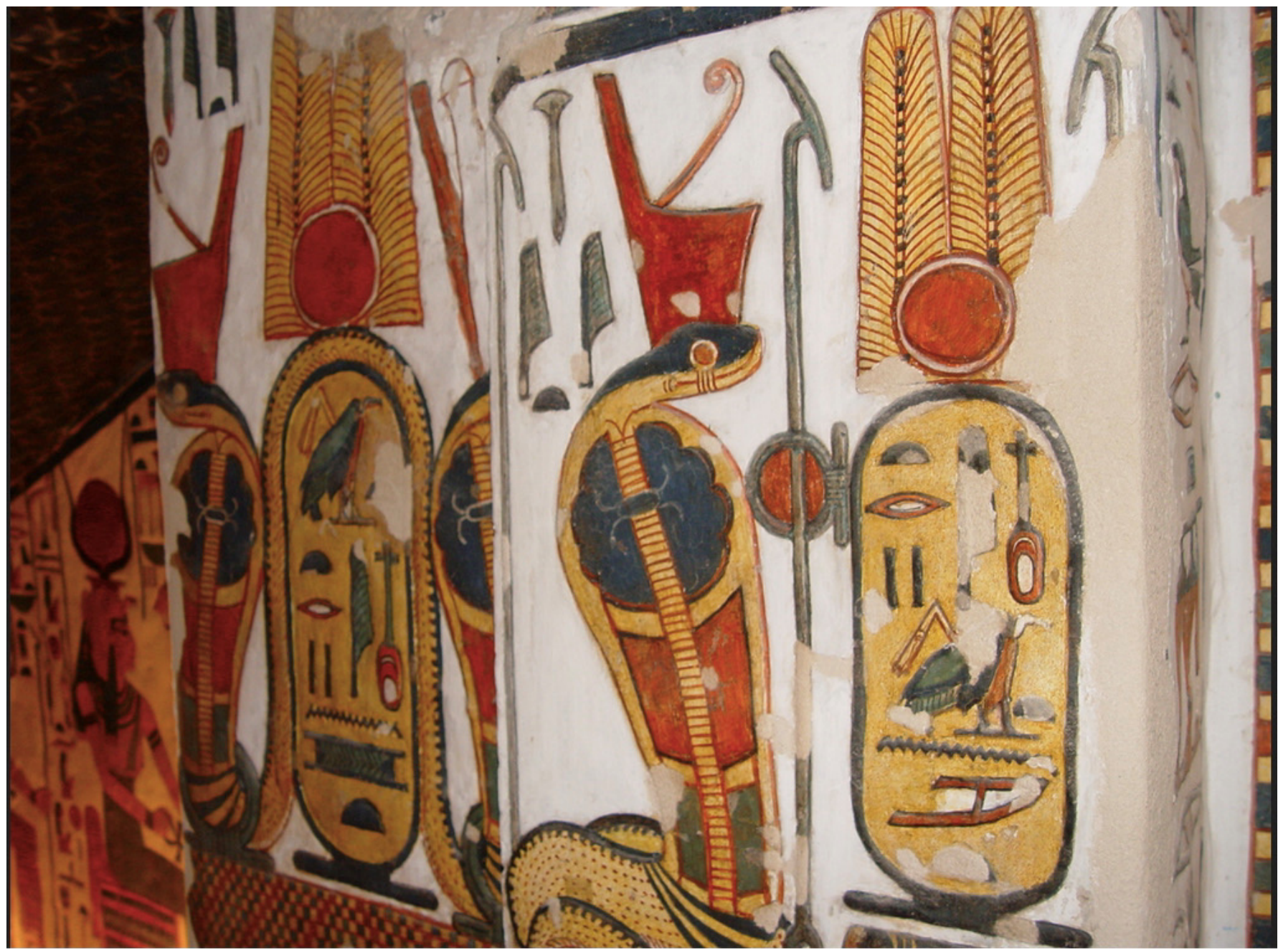

Figure 4. A painted vignette from the tomb (no. 66) of Nofertari in the Valley of the Queens identifying the cobra as the goddess Wadjet. Notice that the hieroglyphs spelling her name are painted green. Courtesy of Venerabilis Opus. http:/ /www.venerabilisopus.org/en/images/1_4_egypt/2_19 _ancient?page=2 and http:/ / www.venerabilisopus.org/en/images/1_4_egypt/2_19_ancient?page=4 (accessed on 22 December 2021).

Wadjet symbolically protects pharaoh, ${ }^{36}$ as she does $\mathrm{Ra}$, the sun god, from all of their enemies. In that role, she is often called "The Mistress of the Flaming Fire" and "The Fiery [left] Eye of Ra." ${ }^{37}$ Additionally, she serves as the one who executes commands on behalf of $\mathrm{Ra}$, particularly in her transformative role recounted in some versions of Myth of the Distant Goddess, which, as discussed earlier, recounts her emphatic transformation from a fierce, raging lioness into a docile, pussy cat. The theological roots of such transformations are inherent in the ancient Egyptian conception of heka, often misleadingly translated simply as "magic." Heka is rather to be understood as the embodiment of the ancient Egyptian theological concept that is best understood as "the ability to change the course of nature." 38 That transformative characteristic of ancient Egyptian religion extends to the principle of alexikakos, literally "averting evil," by which a malevolent force is transformed into a benevolent one. A modern example of that principle is retained in the expression, "fighting fire with fire." The ichneumon, or Egyptian mongoose, a natural predator of snakes in the marshes, ${ }^{39}$ becomes the hypostasis or alternate form of Wadjet. The cobra's natural enemy is thereby transformed into its enabling avatar. 


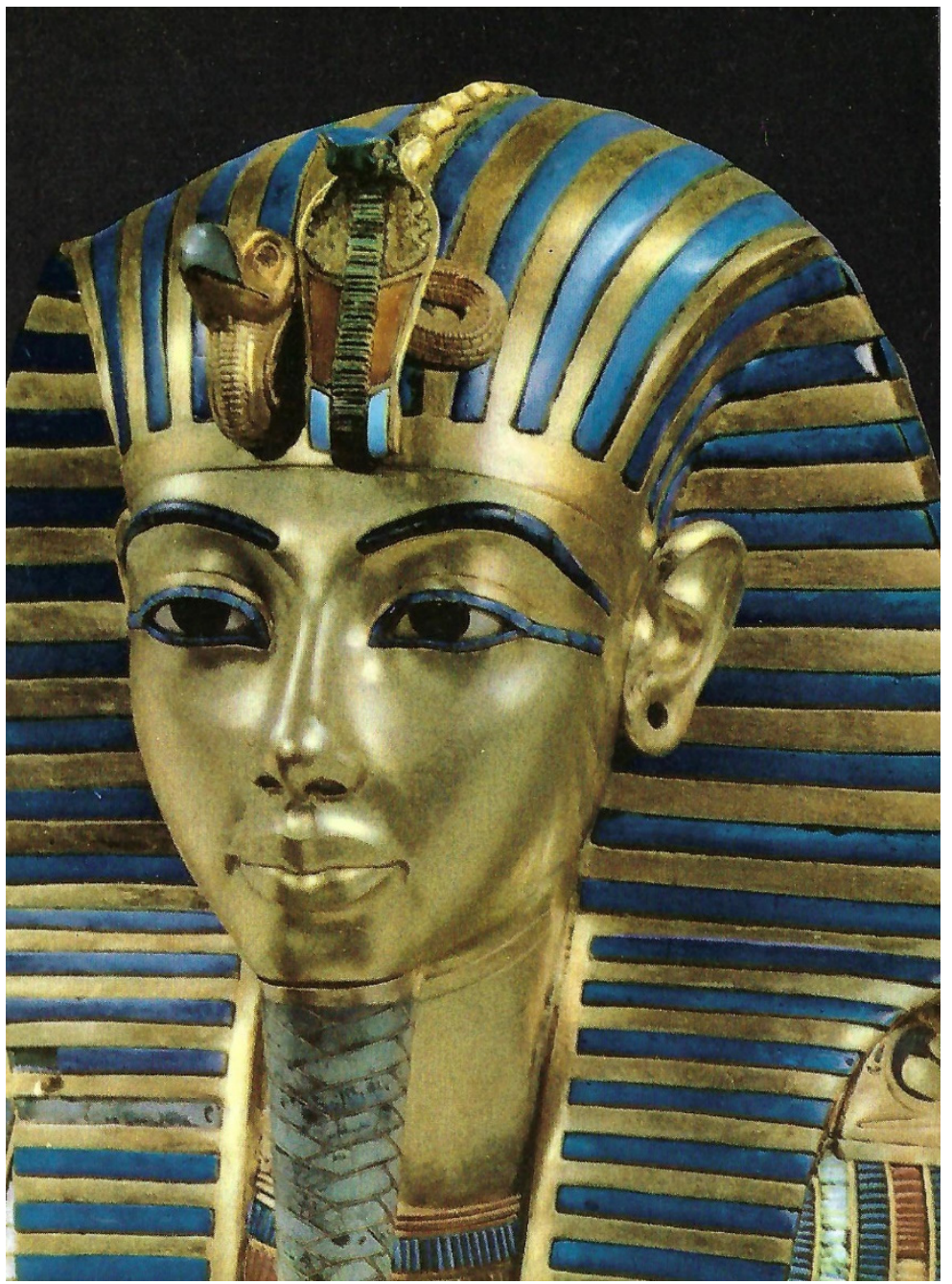

Figure 5. The cobra goddess Wadjet and the vulture goddess, Nekhbet, titulary deities of Lower and Upper Egypt, respectively, adorning the forehead of the third coffin to Tutankhamun, Cairo, The Egyptian Museum, JE 60672. (Courtesy of ALEA-The Archive of Late Egyptian Art-a photographic and bibliographic archive maintained by Dr. Robert Steven Bianchi, Holiday, Florida, USA).

The obelisk in front of which Wadjet stands is another of the coded visual clues exhibited by this object. The ancient Egyptians considered the form of the obelisk as a representation of a ray of the sun, whereas a modern child in the West might represent the rays of the sun as a series of individual lines radiating from the circumference of a circle, the ancient Egyptians conceived the form of a sun's ray as the triangular space formed by two of those adjacent lines projecting from the sun disc. On one level, then, the obelisk visually reinforces Wadjet's relationship to Ra, the sun god. That association furthers her protective role because Wadjet is also associated with the ichneumon, named both $a D$ and $x$ Atrw in the ancient Egyptian language, ${ }^{40}$ representations of which are not to be confused with seemingly similar looking mammals. ${ }^{41}$ The aggressive nature of the ichneumon ${ }^{42}$ is compatible with the bellicose character of Wadjet, whose role in other rituals involving protection using force is well-documented, as seen in Ritual of the Four Balls, which are batted away into the four geographic regions of the cosmos in order to keep malicious powers at bay. ${ }^{43}$ That association must have been fairly well-known in antiquity because it finds its resonance in numerous myths in different ancient cultures, including the Classical myth involving Leto, Apollo, Artemis, and the python, as recorded in Herodotus II, 133 and $156 .{ }^{44}$ (Figure 6) There is at least one Egyptianizing representation, namely a mosaic 
from the Casa del Fauno at Pompeii which depicts "a cobra and an ichneumon facing each other in a hostile manner." 45

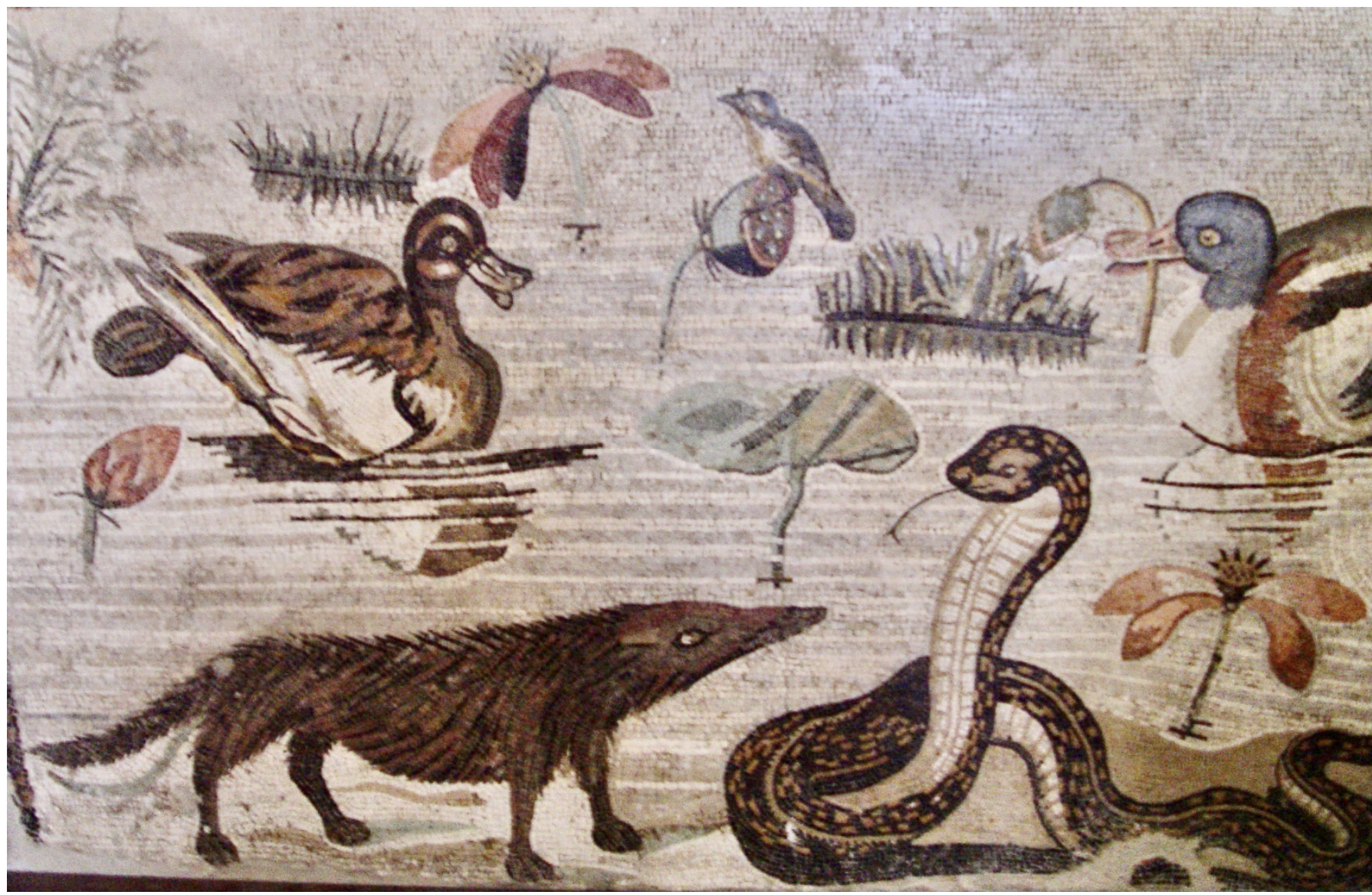

Figure 6. A vignette of the confrontation between an ichneumon and a cobra from the framing element of the mosaic of Alexander the Great, Naples, National Archaeological Museum, 10020. (Courtesy of ALEA-The Archive of Late Egyptian Art-a photographic and bibliographic archive maintained by Dr. Robert Steven Bianchi, Holiday, Florida, USA).

The relationship between Wadjet and the ichneumon is, however, far more complex because of the polyvalent nature of ancient Egyptian theological exegeses. Wadjet was associated with Horus, one of whose cult centers were in the city of Letopolis, located in the Egyptian Delta. The pairing of opposite, antithetical concepts is again operative in this relationship ${ }^{46}$ because Horus of Letopolis was thought to be sight-challenged, whereas Wadjet of Buto was not. In order to articulate that difference, the shrew mouse served as a hypostasis of Horus of Letopolis, whereas the ichneumon, known for its relatively large eyes, ${ }^{47}$ served as that for Wadjet of Buto. ${ }^{48}$ This light-dark dialectic ${ }^{49}$ is furthered by the observation that in other contexts, again consistent with ancient Egyptian theological pairings, one finds Wadjet of "today" coupled with Sakhmet of "yesterday," further reinforced by the ichneumon's association with concepts of brightness. ${ }^{51}$

It has been cogently argued that bronze statuettes representing Wadjet served as reliquaries containing the mummified remains of ichneumons, one of her hypostases. An inventory of a dozen such objects in Berlin suggests that $75 \%$ contained the remains of an ichneumon, ${ }^{52}$ (Figure 7) although whether that observation was based on visual or forensic evidence is unclear. Some of those reliquaries, such as the one under discussion and its parallel in Leiden, are in the form of an obelisk, which is often associated with the god Osiris who could be represented as an obelisk..$^{53}$ Texts associated with reliquaries from numerous animal cemeteries which dotted the Egyptian landscape during the course of the 
Late Period, ${ }^{54}$ from the seventh century BCE onwards, routinely identify the mummified animal within as Osiris. ${ }^{55}$ Because the cult of the goddess Wadjet at Buto was associated with Osiris, the use of an obelisk as the form of the reliquary in which an ichneumon, one of her hypostases, was contained reinforces the identity of the housed ichneumon with that god. Once ensconced within the symbolic body of Osiris, represented by the obelisk, the mummified ichneumon "becomes" Osiris via the principle of assimilation. ${ }^{56}$ Such a symbolic assimilation is again an ample demonstration of the complexities inherent in ancient Egyptian religious exegeses, which is characterized by polyvalence. These same conceits are present in a third example in Berlin inscribed as well for Wadjet. ${ }^{57}$ In this object, Wadjet is enthroned, rather than standing, in front of the obelisk, said to contain the bones of an ichneumon, with her fisted hands placed asymmetrically on her thighs. Her attribute is a composite crown consisting of lyre-formed horns framing a sun disc and two tall plumes, which link her theologically with the goddess Hathor. ${ }^{58}$

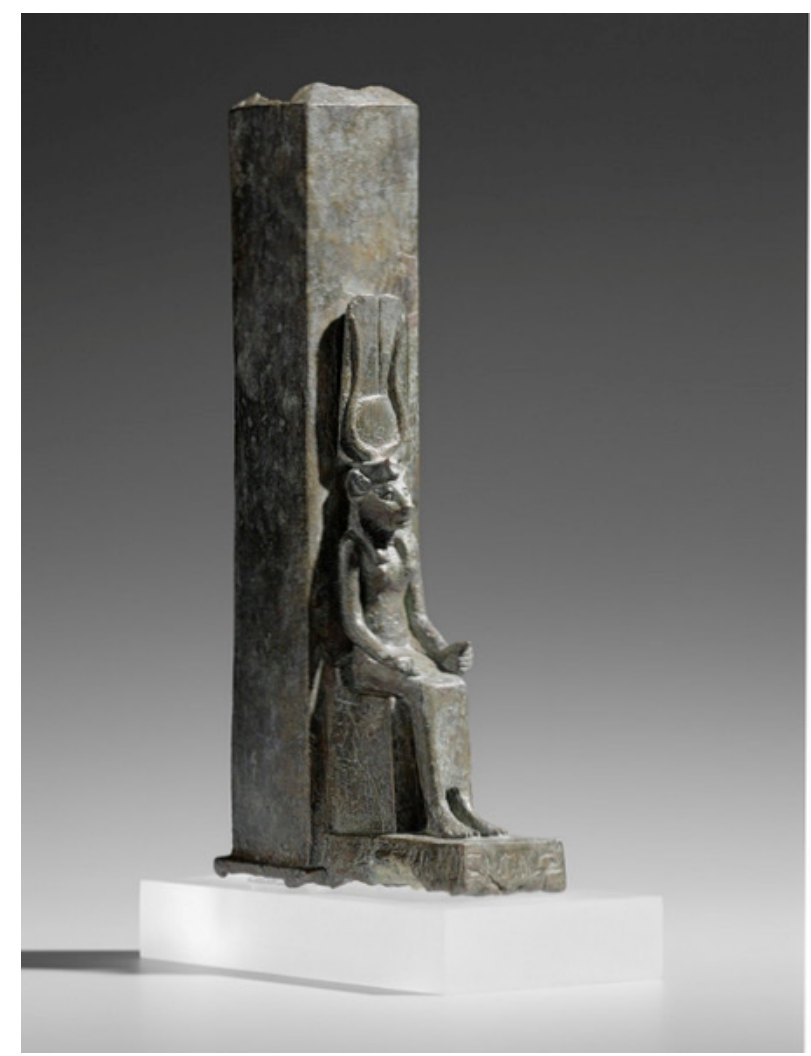

Figure 7. A bronze reliquary for an ichneumon inscribed for the Egyptian goddess Wadjet. Berlin, Ägyptisches Museum und Papyrussamlung, Staatliche Museen 13142. CFoto: Ägyptisches Museum und Papyrussamlung, Staatliche Museen zu Berlin Fotografin: Sandra Steiss. SMB-digital is licensed under a Creative Commons Attribution-NonCommercial-ShareAlike 3.0 Germany License.

It has been suggested that such bronze objects housing the remains of mummified animals served ancient Egyptians as either please or thank you offerings, in anticipation of an aspired benefaction or in gratitude for one having been obtained. Others take exception to this platitude by maintaining that such offerings are linked to elite religious, royal rituals of renewal and cosmic regeneration. ${ }^{59}$ The raising of such animals, their mummification, the manufacturing of the reliquaries in which those remains were housed, and their eventual transfer to those using them in such rituals are all part of a complex, interlocking industrial system that positively impacted the economy of the nation. ${ }^{60}$ (Figure 8 ). 


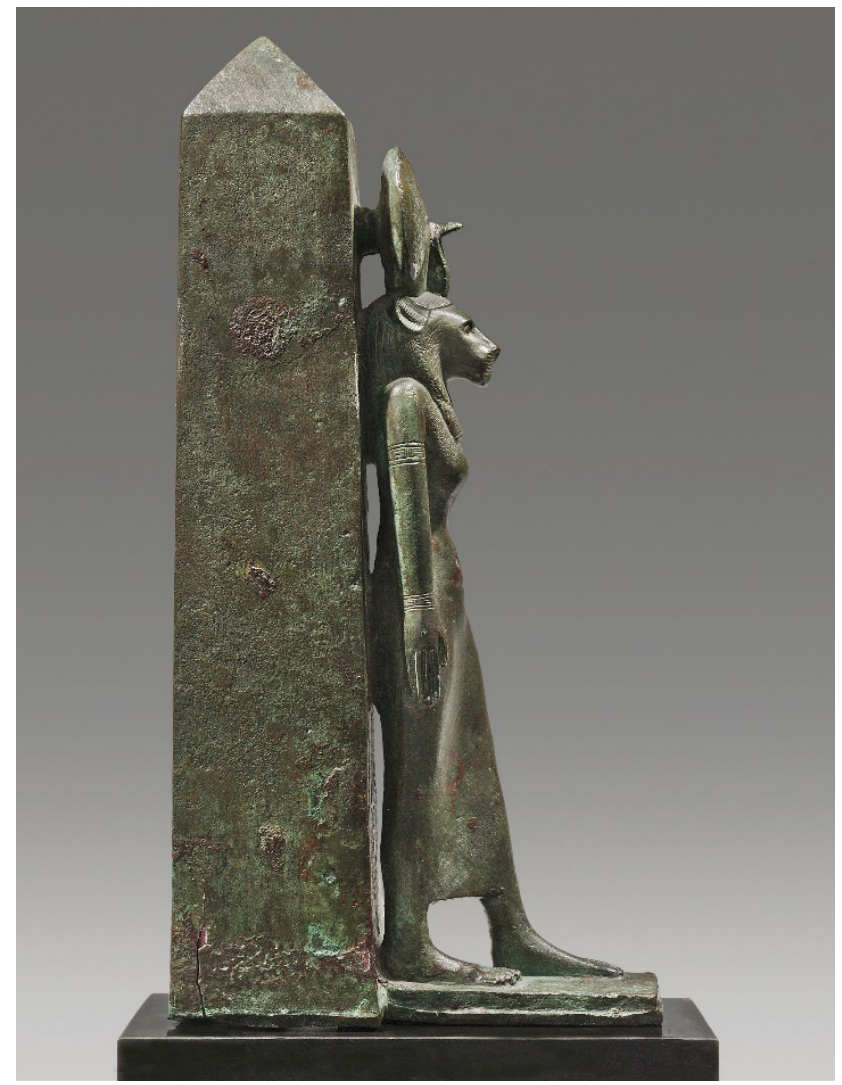

Figure 8. A bronze reliquary for an ichneumon dedicated to the Egyptian goddess Wadjet, right side. (Private collection, courtesy of the owner).

The dating of this particular bronze object may be suggested by its stylistic characteristics. The three components elements of its composition are a leonine-headed goddess, an obelisk, and the partially preserved plinth on which the goddess strides forth with her advanced left leg. The coalescence of her wig, buttocks, and heel of her right foot against the obelisk together with the presence of the horizontal strut between the center of the sun disc upon her head and the obelisk suggests that all three elements were modeled together before the being hollow cast via the lost wax technique. The smooth surfaces of all of the incised details, which do not exhibit burrs, indicated that those details were already introduced into the wax matrix, which was enveloped before the metal was poured; they were not cold-worked after the cast was made. Although attested earlier, metal casting via the lost wax technique gained ascendancy in Egypt during the Third Intermediate Period. A majority of metal objects created during that period are of exceptionally large dimensions and are frequently inlaid with secondary materials. The dimensions of the figure of Wadjet in this object and the absence of secondary inlays would suggest that it was created during the Late Period, between the seventh and late fourth century BCE. Such a dating is reinforced by the feline design of her ears. A later date for the creation of this group into the Ptolemaic period can be excluded because ears of felines created during that era resemble human ears, often attributed to that epoch's perceived humanistic tendencies. ${ }^{61}$

Funding: This research received no external funding.

Acknowledgments: The author thank the members of the editorial board of ZOA for their comments and suggestions and wish to recognize Kyria Marcella Osborne for her service in copy-editing this essay.

Conflicts of Interest: The authors declare no conflict of interest. 
Websites: Berlin, Ägyptisches Museum und Papyrussammlung 13144: http:/ / www.smb-digital.de/ eMuseumPlus? service $=$ ExternalInterface $\&$ module $=$ collection \&objectId $=591642 \&$ viewType $=$ detailView (accessed on 24 September 2021).Leiden, Rijksmuseum van Oudheden, F 1953/5.2: https:/ / www.rmo. $\mathrm{nl} /$ collectie/collectiezoeker/collectiestuk/ ?object=13099 (accessed on 24 September 2021).Lionesses with Manes: https: / www.newscientist.com/article/2106866-five-wild-lionesses-grow-a-mane-andstart-acting-like-males / (accessed on 23 September 2021).

\section{Notes}

(Fischer 1986).

(Gardiner 1969, p. 31, §23) and (Goldwasser 2002).

(Shalomi-Hen 2019, p. 373) and (Richter 2019).

(Thuault 2017).

(Houston and Stauder 2020).

(Rashwan 2019, p. 166).

(Hornung 1992, pp. 30-45).

(Di Biase-Dyson 2014, p. 106).

(Cooney 2021, p. 24).

(Cauville 2007, Vol. 1, p. xvi).

(Cauville 2007, Vol. 1, p. xvi).

(Bussmann 2019).

(Broze 2006).

(Collection de feu Omar Pacha Sultan 1929, cat. no. 81 and p. 81), where the leonine deity is identified as "Sekhmet." I thank the present owner for permission to publish this object and for providing me with the photographs.

(Meeks 1986).

(Dolzani 1989).

https:/ / www.newscientist.com/article/2106866-five-wild-lionesses-grow-a-mane-and-start-acting-like-males / (accessed on 23 September 2021).

(Kilany and Mahran 2015).

(Evans 2010, p. 122).

(Kwiecinski 2019).

((Bianchi forthcoming).

(Lashien 2020).

(Leitz 2018).

(Yoyotte 1988, pp. 155-78).

(Hastings 1997, p. 40).

Inter alia, (Inconnu-Bocquillon 2001; Richter 2010), for the polyvalence of interlocking mythologies woven into the core myth; and (Étienne 2000, pp. 25-26), for a concise summary.

(Louarn 2020), for the significance in this myth of goddesses "behaving as men," as an expression of a breach of the normative to express "the other," and thereby inspire fear.

(Lippert 2012), for the pairings of lions and cats.

(Vandier 1967).

Leiden, Rijksmuseum van Oudheden, F 1953/5.2: https: / /www.rmo.nl/collectie/collectiezoeker/collectiestuk/?object=13099 (accessed on 24 September 2021) incorrectly identifies this image as Sakhmet, apparently ignoring the inscription on the base. That error is corrected in the catalogue entry by (Schneider and Raven 1981, pp. 134-35, no. 137).

(Desroches Noblecourt 1996); and (Di Biase-Dyson and Chantrain 2021, p. 613).

(Hartung 2018).

(Ballet 2011; Bedier 1994); and (Lloyd 1982, p. 175, note 31).

(Töpfer 2018).

(Gamelin 2021, p. 68).

(Bosse-Griffiths 1973).

(Étienne 2000, pp. 25-26); and (Szpakowska 2011, pp. 70-1); and (Shaw and Nicholson 1995)

(Jacco 2019, p. 96). 


\section{References}

Ballet, Pascale. 2011. De Per Ouadjyt à Bouto (Tell el-Fara'in): Un grand centre urbain du delta égyptien de la fin de la basse époque à l'antiquité tardive. Comptes Rendus des Séances de l'Académie des Inscriptions E Belles-Lettres 155: 1567-89.

Bedier, Shafa. 1994. Ein Stiftungsdekret Thutmosis' III. aus Buto. In Aspekte Spätägyptischer Kultur: Festschrift für Erich Winter Zum 65. Geburtstag. Edited by Minas Martina and Jürgen Zeidler. Mainz: Philipp von Zabern, pp. 35-50.

Bell, Lanny. 2002. Divine kingship and the theology of the obelisk cult in the temples of Thebes. In 5. Ägyptologische Tempeltagung: Würzburg, 23-26 September 1999. Edited by Beinlich Horst, Jochen Hallof, Holger Hussy and Christiane von Pfeil. Wiesbaden: Harrassowitz, pp. 17-46.

Bianchi, Robert Steven. forthcoming. A group of vessels in the shape of horned, African ruminants. Beitrage zur Sudanarchologie, unpublished.

Bosse-Griffiths, Kate. 1973. The Great Enchantress in the little golden shrine of Tut'ankhamūn. Journal of Egyptian Archaeology 59: 100-8. Bothmer, Bernard V. 1949. Statuettes of WAD.t as ichneumon coffins. Journal of Near Eastern Studies 8: 121-23. [CrossRef]

Brentjes, Burchard. 1967. Schleichkatzen (Viverridae) und Marder (Mustelidae) in der Kultur des alten Orients. Saugetierkundliche Mitteilungen 15: 304-17.

Broze, Michèle. 2006. Dessiner les dieux en Égypte ancienne: Créer avec l'image et créer avec les mots. In Sphinx: Les Gardiens de l'Égypte. Edited by Warmenbol Eugène. Brussels: Mercator, pp. 123-31.

Brunner-Traut, Emma. 1980. Ichneumon. In Lexikon der Ägyptologie III: Horhekenu-Megebr. Edited by Helck Wolfgang and Wolfhart Westendorf. Wiesbaden: Otto Harrassowitz, cols., pp. 122-33.

Bussmann, Richard. 2019. Practice, meaning and intention: Interpreting votive objects from ancient Egypt. In Perspectives on Lived Religion: Practices-Transmission —Landscape. Edited by Staring Nico, Huw Twiston Davies and Lara Weiss. Leiden: Sidestone Press, pp. 73-84.

Cauville, Sylvie. 2007. Dendara: Le Temple d'Isis. 2 vols. Cairo: Institut Français d'Archéologie Orientale.

Collection de feu Omar Pacha Sultan, le Caire: Catalogue Descriptif: I. Art Egyptien. II. Art Musulman. 1929. Paris: Librairie de France.

Cooney, Kathlyn M. 2021. Coffin Commerce: How a Funerary Materiality Formed Ancient Egypt. Cambridge Elements: Elements in Ancient Egypt in Context. Cambridge: Cambridge University Press. 
Coulon, Laurent. 2011. Les uræi gardiens du fétiche abydénien: Un motif osirien et sa diffusion à l'époque saïte. In La XXVIe Dynastie, Continuités et Ruptures: Actes du Colloque International Organisé les 26 et 27 Novembre 2004 à l'Université Charles-de-Gaulle-Lille 3; Promenade Sä̈te Avec Jean Yoyotte. Edited by Devauchelle Didier. Paris: Cybele, pp. 85-108.

Davies, Sue. 2007. Bronzes from the Sacred Animal Necropolis at North Saqqara. In Gifts for the Gods: Images from Egyptian Temples. Edited by Hill Marsha and Deborah Schorsch. New Haven, London and New York: Yale University Press, The Metropolitan Museum of Art, pp. 174-87.

Delhez, Julien. 2013. Considérations d'Hérodote sur la loutre, la mangouste-ichneumon et la musaraigne. Research Antiquae 10: 131-56.

Desroches Noblecourt, Christiane. 1996. Les déesses et le sema-taouy. In Studies in Honor of William Kelly Simpson. Edited by Manuelian Peter Der. Boston: Department of Ancient Egyptian, Nubian and Near Eastern Art, Museum of Fine Arts, vol. 1, pp. $191-97$.

Di Biase-Dyson, Camilla. 2014. Multiple dimensions of interpretation: Reassessing the magic brick Berlin ÄMP 15559. Studien zur Altägyptischen Kultur 43: 93-107.

Di Biase-Dyson, Camilla, and Gaëlle Chantrain. 2021. Metaphors of sensory experience in ancient Egyptian texts. Emotion, personality, and social interaction. In The Routledge Handbook of the Senses in the Ancient Near East. Edited by Naumann Kiersten and Allison Thomason. Oxfordshire: Routledge, pp. 603-35.

Dolzani, Claudia. 1989. Aspetti e problemi del culto degli animali nella religione egiziana. In Akten des Vierten Internationalen Ägyptologen Kongresses München 1985. Band 3: Linguistik, Philologie, Religion, 231-240. Edited by Schoske Sylvia. Hamburg: Busk, p. 3.

Étienne, Marc. 2000. Heka: Magie et Envoûtement Dans l'Égypte Ancienne. Les Dossiers du Musée du Louvre 57. Paris: Réunion des Musées Nationaux.

Evans, Linda. 2010. Otter or mongoose? Chewing over evidence in wall scenes. In Egyptian Culture and Society: Studies in Honour of Naguib Kanawati. Edited by Woods Alexandra, Ann McFarlane and Susanne Binder. Cairo: Conseil Suprême des Antiquités, vol. 1, pp. 119-29.

Evans, Linda. 2016. Beasts and beliefs at Beni Hassan: A preliminary report. Journal of the American Research Center in Egypt 52: 219-29. [CrossRef]

Fischer, Henry George. 1986. L'écriture et L'art de l'Égypte Ancienne: Quatre Leçons sur la Paléographie et L'épigraphie Pharaoniques. Essais et Conférences. Paris: Presses Universitaires de France.

Fischer-Elfret, Hans-Werner. 1986. Uto. In Lexikon der Ägyptologie VI: Stele-Zypresse. Edited by Helck Wolfgang and Wolfhart Westendorf. Wiesbaden: Otto Harrassowitz, cols, pp. 906-11.

Flossmann-Schütze, Mélaine. 2017. Études sur le cadre de vie d'une association religieuse dans l'Égypte gréco-romaine: L'exemple de Touna el-Gebel. In Proceedings of the XI International Congress of Egyptologists, Florence Egyptian Museum, Florence, 23-30 August 2015. Edited by Rosati Gloria and Maria Cristina Guidotti. Oxford: Archeopress, pp. 203-8.

Gamelin, Th. 2021. Divinités et génies ailés en Égypte ancienne-Protecteurs et dispensateurs de vie. Kasion 6: 57-92.

Gardiner, Alan H. 1969. Egyptian Grammar: Being an Introduction to the Study of Hieroglyphs. Oxford: Clarendon Press.

Goldwasser, Orly. 2002. Prophets, Lovers and Giraffes: Wor(l)d Classification in Ancient Egypt. Classification and Categorization in Ancient Egypt 3, Göttinger Orientforschungen, 4. Reihe: Ägypten 38. Wiesbaden: Harrassowitz.

Graindorge, Catherine. 1996. La quête de la lumière au mois de Khoiak: Une histoire d'oies. Journal of Egyptian Archaeology 82: 83-105.

Hartung, Ulrich. 2018. Buto I: The city's early history. Egyptian Archaeology 53: 30-32.

Hastings, Elizabeth Anne. 1997. The Sculpture from the Sacred Animal Necropolis at North Saqqāra 1964-1976. Egypt Exploration Society, Excavation Memoir 61. London: Egypt Exploration Society.

Hornung, Erik. 1992. Idea into Image: Essays on Ancient Egyptian Thought. Translated by Elizabeth Bredeck. New York: Timken.

Houston, Stephen, and Andréas Stauder. 2020. What is a hieroglyph? L'Homme: Revue Française D'Anthropologie 233: 9-44. [CrossRef] Ikram, Salima. 2015. Speculations on the role of animal cults in the economy of ancient Egypt. In Apprivoiser le Sauvage/Taming the Wild. Edited by Magali Massiera, Bernard Mathieu and Frédéric Rouffet. Montpellier: Université Paul Valéry Montpellier 3, pp. 11-227.

Inconnu-Bocquillon, Danielle. 2001. Le Mythe de la Déesse Lointaine à Philae. Bibliothèque D'étude 132. Le Caire: Institut Français D'archéologie Orientale.

Jacco, Dieleman. 2019. The Greco-Egyptian magical papyri. In Guide to the Study of Ancient Magic. Edited by David Frankfurter. Guide to the study of ancient magic. Religions in the Graeco-Roman world. Leiden: Brill, vol. 189, pp. 283-321.

James, Thomas Garnet Henry. 1982. The wooden figure of Wadjet with two painted representations of Amasis. Journal of Egyptian Archaeology 68: 156-65. [CrossRef]

Kessler, Dieter. 2005. Tierische Missverständnisse: Grundsätzliches zu Fragen des Tierkultes. In Tierkulte im Pharaonischen Ägypten und im Kulturvergleich. Edited by Fitzenreiter Martin. London: Golden House, pp. 33-67.

Kilany, Engy El, and Heba Mahran. 2015. What lies under the chair! A study in ancient Egyptian private tomb scenes. Part I: Animals. Journal of the American Research Center in Egypt 51: 243-64. [CrossRef]

Kurth, Dieter. 1990. Der Sarg der Teüris: Eine Studie Zum Totenglauben im Römerzeitlichen Ägypten. Aegyptiaca Treverensia: Trierer Studien Zum Griechisch-Römischen Ägypten 6. Mainz am Rhein: Philipp von Zabern.

Kwiecinski, Jakub M. 2019. Depictions of crocodiles and scorpions in Predynastic and early Dynastic Egypt: The case of the Abydos flint animals. Göttinger Miszellen 257: 97-107.

Lashien, Miral. 2020. Donkeys in the Old and Middle Kingdoms according to the representations and livestock counts from private tombs. Études et Travaux 33: 121-37. [CrossRef] 
Leitz, Christian. 2018. Einige Bezeichnungen für kleine und mittelgroße Säugetiere im Alten Ägypten. Bulletin de l'Institut Français d'Archéologie Orientale 118: 241-67. [CrossRef]

Lippert, Sandra Luisa. 2012. Stachelschwein, Igel und Schmetterlingspuppe. In "Parcourir l'éternité": Hommages à Jean Yoyotte. Edited by Zivie-Coche Christiane and Ivan Guermeur. Turnhout: Brepols, vol. 2, pp. 777-99.

Lloyd, Alan B. 1982. The inscription of Udjahorresnet: A collaborator's testament. Journal of Egyptian Archaeology 68: 166-80.

Louarn, Adrien. 2020. Agir en mâle, étant une femme. Égypte Nilotique et Méditerranéenne 13: 311-17.

Meeks, Dimitri. 1986. Zoomorphie et image des dieux dans l'Égypte ancienne. In Corps des Dieux. Edited by Malamoud Charles and Jean-Pierre Vernant. T emps de la réflexion 7. Paris: Gallimard, pp. 171-91.

Rashwan, Hany. 2019. Ancient Egyptian image-writing: Between the unspoken and visual poetics. Journal of the American Research Center in Egypt 55: 137-60. [CrossRef]

Richter, Barbara A. 2010. On the heels of the Wandering Goddess: The myth and the festival at the temples of the Wadi el-Hallel and Dendera. In 8. Ägyptologische Tempeltagung: Interconnections between Temples, Warschau, 22-25 September 2008. Edited by Dolińska Monika and Horst Beinlich. Wiesbaden: Harrassowitz, pp. 155-86.

Richter, Barbara A. 2019. Gods, priests, and bald men: A new look at Book of the Dead 103 ("being beside Hathor"). In The Book of the Dead, Saite through Ptolemaic Periods: Essays on Books of the Dead and Related Materials. Edited by Mosher Malcolm, Jr. Prescott: Malcolm Mosher, Jr., pp. 519-40.

Roeder, Günther. 1956. Ägyptische Bronzefiguren. 2 vols. Mitteilungen aus der Ägyptischen Sammlung 6. Berlin: N.p. At head of title: Staatliche Museen zu Berlin.

Rowland, Joanne, Salima Ikram, Geoffrey J. Tassie, and Lisa Yeomans. 2013. The sacred falcon necropolis of Djedhor(?) at Quesna: Recent investigations from 2006-2012. Journal of Egyptian Archaeology 99: 53-84.

Sainte Fare Garnot, Jean. 1937. Le lion dans l'art égyptien. Bulletin de l'Institut Français d'Archéologie Orientale 37: 75-91.

Schneider, Hans D., and Maarten J. Raven. 1981. De Egyptische Oudheid: Een Inleiding aan de Hand van de Egyptische Verzameling in Het Rijksmuseum van Oudheden to Leiden. 's-Gravenhage: Staatsuitgeverij.

Shalomi-Hen, Racheli. 2019. The two kites and the Osirian revolution. In Old Kingdom Art and Archaeology 7: Proceedings of the International Conference; Università Degli Studi di Milano 3-7 July 2017. Edited by Piacentini Patrizia and Alessio Delli Castelli. Milano: Pontremoli, vol. 1, pp. 372-77.

Shaw, Ian, and Paul Nicholson. 1995. British Museum Dictionary of Ancient Egypt. London: British Museum Press.

Sweeney, Deborah, Christian Herrmann, Ido Koch, Yuval Gadot, Manfred Oeming, and Oded Lipschits. 2018. A triad amulet from Tel Azekah. Israel Exploration Journal 68: 129-49.

Szpakowska, Kasia. 2011. Demons in the dark: Nightmares and other nocturnal enemies in ancient Egypt. In Ancient Egyptian Demonology: Studies on the Boundaries between the Demonic and the Divine in Egyptian Magic. Edited by Kousoulis Panagiotis. Leuven: Peeters, Departement Oosterse Studies. pp. 63-76.

Thuault, Simon. 2017. Research on Old Kingdom "dissimilation graphique": World-view and categorization. In Proceedings of the XI International Congress of Egyptologists, Florence Egyptian Museum, Florence, 23-30 August 2015. Edited by Rosati Gloria and Maria Cristina Guidotti. Oxford: Archeopress, pp. 633-37.

Töpfer, Susanne. 2018. The body of the king and of the goddess: Materiality in and through manuals for Pharaoh from Tebtunis. In The Materiality of Texts from Ancient Egypt: New Approaches to the Study of Textual Material from the Early Pharaonic to the Late Antique Period. Edited by Hoogendijk Francisca A.J. and Steffie van Gompel. Leiden and Boston: Brill, pp. 35-42.

Vadas, Réka. 2020. "The beautiful place of kyphi and wine": The laboratory at Esna temple. Égypte Nilotique et Méditerranéenne 13: 93-132.

Vandier, Jacques. 1967. Ouadjet et l'Horus léontocéphale de Bouto: À propos d'un bronze du Musée de Chaalis. Monuments et Mémoires de la Fondation Eugène Piot 55: 7-75. [CrossRef]

Velde, H. Te. 1980. A few remarks upon the religious significance of animals in ancient Egypt. Numen 27: 76-82.

Vernus, Pascal, and Jean Yoyotte. 2005. Bestiaire des Pharaons. Paris: Agnès Viénot, Perrin.

Versluys, Miguel J. 2002. Aegyptiaca Romana: Nilotic Scenes and the Roman Views of Egypt. Religions in the Graeco-Roman World 144. Leiden and Boston: Brill.

Yoyotte, Jean. 1988. Des lions et des chats: Contribution à la prosopographie de l'époque libyenne. Revue D'égyptologie 39: 155-78. [CrossRef]

Ziegler, Christiane. 1979. À propos du rite des quatre boules. Bulletin de l'Institut Français d'Archéologie Orientale 79: 437-39. 